\title{
Cross-mapping of results and Nursing Interventions: contribution to the practice
}

\author{
Mapeamento cruzado de resultados e intervenções de enfermagem: contribuição para a prática \\ Mapeo cruzado de resultados e intervenciones de enfermería: contribución a la práctica
}

\section{Sheila Coelho Ramalho Vasconcelos Morais', Maria Miriam Lima da Nóbrega", Emilia Campos de Carvalho' \\ ' Universidade de São Paulo, Nursing School of Ribeirão Preto. Ribeirão Preto, São Paulo, Brazil. \\ "Universidade Federal da Paraíba, Public Health and Psychiatry Nursing Department. João Pessoa, Paraíba, Brazil.}

\section{How to cite this article:}

Morais SCRV, Nóbrega MML, Carvalho EC. Cross-mapping of results and Nursing Interventions: contribution to the practice. Rev Bras Enferm [Internet]. 2018;71(4):1883-90. DOI: http://dx.doi.org/10.1590/0034-7167-2017-0324

Submission: 05-11-2017 Approval: 07-05-2017

\begin{abstract}
Objective: To evaluate, through cross-mapping, the correspondence of the expected results and prescriptions written by nurses among those contained in the Interventions Classifications and Nursing Results, for the diagnosis "Ineffective peripheral tissue perfusion". Method: Descriptive study, using the case study and the mapping. The content of the case study was validated, with a rate of $93.75 \%$. In the mapping of the statements of the nursing phenomena, written by the participants with the standardized language systems, a concordance index of $100 \%$ and $90 \%$ was obtained. Results: Three statements of expected results and 19 prescribed care were analyzed. Of these, four presented correspondences with the classification of results and the same number with the classification of the interventions. Conclusion: The mapping allowed the correspondence of the terms adopted by the nurses with the standardized language systems and showed a didactic material to verify the pertinence of the decision making. Descriptors: Nursing; Nursing Processes; Ranking; Nursing Care; Education in Nursing.
\end{abstract}

\section{RESUMO}

Objetivo: Avaliar, por meio do mapeamento cruzado, a correspondência dos resultados esperados e prescrições redigidas por enfermeiros entre os contidos nas Classificações das Intervenções e de Resultados de enfermagem, para o diagnóstico "Perfusão tissular periférica ineficaz". Método: Estudo do tipo descritivo, com a utilização do estudo de caso e do mapeamento. Foi realizada a validação de conteúdo do estudo de caso, com índice de 93,75\%. No mapeamento dos enunciados dos fenômenos de enfermagem, redigidos pelos participantes com os sistemas de linguagens padronizadas, obteve-se um índice de concordância de 100\% e 90\%. Resultados: Foram analisados 3 enunciados de resultados esperados e 19 cuidados prescritos. Destes, quatro apresentaram correspondências com a classificação de resultados e igual número com a classificação das intervenções. Conclusão: O mapeamento possibilitou a correspondência dos termos adotados pelos enfermeiros com os sistemas de linguagens padronizadas e se mostrou um material didático para verificar a pertinência da tomada de decisão.

Descritores: Enfermagem; Processos de Enfermagem; Classificação; Cuidados de Enfermagem; Educação em Enfermagem.

\section{RESUMEN}

Objetivo: Evaluar, por medio del mapeo cruzado, la correspondencia de los resultados esperados y prescripciones redactadas por enfermeros entre los contenidos en las Clasificaciones de las Intervenciones y de Resultados de enfermería, para el diagnóstico "Perfusión tisular periférica inefectiva". Método: Estudio del tipo descriptivo, con la utilización del estudio de caso y del mapeo. Se realizó la validación del contenido del estudio de caso, con índice del 93,75\%. En el mapeo de los enunciados de los fenómenos de enfermería, redactados por los participantes con los sistemas de lenguajes estandarizados, se obtuvo un índice del $100 \%$ y del $90 \%$. Resultados: Fueron analizados 3 enunciados de resultados esperados y 19 cuidados prescritos. De estos, cuatro presentaron correspondencia con la clasificación de resultados e igual número con la clasificación de las intervenciones. 
Conclusión: El mapeo posibilitó la correspondencia de los términos adoptados por los enfermeros con los sistemas de lenguajes estandarizados y se mostró un material didáctico para verificar la pertinencia de la toma de decisión.

Descriptores: Enfermería; Procesos de Enfermería; Clasificación; Cuidados de Enfermería; Educación en Enfermería.

\section{INTRODUCTION}

The nursing process involves a set of measures that begins in the identification and naming of the problems, answers or needs of the individual, family or community follows to the planning of the expected results and selection of the appropriate actions to obtain them; and conclude with the evaluation of the results achieved. In this framework, cognitive and technical skills are essential for clinical nursing decision making.

Thus, the professional thinking and doing can be represented by the Nursing Process (NP), or process of clinical reasoning in nursing(1) that must be registered in the patient's medical records or in the nursing's own forms, according to the legal requirements of the profession ${ }^{(2-3)}$.

The registry of clinical decisions includes the set of data that result in diagnoses, interventions and nursing outcomes achieved. This formal registration is a fundamental requirement for the health information system and, when supported in a standardized language system (SLS), enables interdisciplinary communication, facilitates quality assessment of care, promotes patient and professional safety, provides institutional information about the patient and provides the development of science, the production of knowledge and the contribution of nursing in the different care settings ${ }^{(4-9)}$.

An SLS is considered to organize information and its existence is related to the development of knowledge of the nursing discipline by enabling the organization of knowledge and the construction of databases in relation to nursing diagnoses, interventions or results, besides giving visibility for nursing's contribution to people's health ${ }^{(4)}$. Obstacles to its implementation are verified in Brazilian nursing, especially because of the difficulty and lack of knowledge of nurses to name the phenomena using a standardized language ${ }^{(10)}$. There are several SLSPs to name nursing phenomena, such as the NANDA-I Nursing Diagnostic Classification $^{(11)}$, the Nursing Interventions Classification (NIC) ${ }^{(12)}$ and the Nursing Outcomes Classification (NOC) ${ }^{(13)}$.

It should be mentioned that $\mathrm{NOC}^{(13)}$ was developed in 1991 and published in 1997. It is considered complementary to the taxonomy of NANDA-I ${ }^{(11)}$ and $\mathrm{NIC}^{(12)}$, and its structure consists of 7 domains, 32 classes and 490 results. The meaning of results of nursing-sensitive patients relates to a "state, behavior or perception of the individual, family or community measured along a continuum in response to an intervention"(13).

As for $\mathrm{NIC}^{(12)}$, this classification emerged in 1987 and is currently organized in 7 domains, 30 classes and 554 nursing interventions with approximately 13 thousand activities. An intervention is defined as: "any treatment, based on clinical judgment and knowledge, performed by a nurse to improve patient/client outcomes." To facilitate nurses' clinical decision making, the NIC lists nursing interventions organized at three levels: priority, suggested and optional(12) for each diagnosis.
In Brazil, when developing the Nursing Process, many teaching and service institutions adopt free cursive writing - the goals and objectives to be achieved for/by the patient - as opposed to using a pre-determined Classification for the identification of results expected in nursing care planning. Likewise, the elaboration of prescriptions sometimes portrays the professional's experience and not the systematic search for the actions listed by a Classification of interventions, for example. Thus, the use of taxonomies in the daily routine of Brazilian nursing is still a challenge in several contexts ${ }^{(8)}$.

Faced with such a framework, it is a matter of discussion about teaching, during the training and improvement of nurses, tools that allow the development of clinical reasoning and the use of SLSs as an organizing element of clinical practice.

It is therefore relevant to point out, among the teaching tools, the contribution of the case study, indicated to facilitate this learning and that allows to use theoretical references and standardized languages in the care process ${ }^{(14)}$.

Added to the case study is the cross-mapping strategy as a facilitator in this teaching and learning course by giving visibility to the professional's clinical thinking process; In this sense, considering the care register done by the professional without the use of the standardized language, mapping it with reference SLS, may allow to identify voids of the knowledge or enable analysis of other viable strategies, but not usual in a given situation or context.

Some studies have pointed out the result of the cross-mapping by relating the terms of the nursing records to those contained in the Classification of Nursing Interventions (NIC) ${ }^{(12)}$, in medical records of patients with Parkinson's disease ${ }^{(15)}$; or the presentation in an intensive care unit ${ }^{(16)}$ of the mapping of diagnostic titles with the theory of basic human needs and nursing actions with the interventions proposed by the NIC; another still ${ }^{(17)}$ portrayed, in wound care, the terms adopted by nursing mapped with the interventions and nursing results contained in the $\mathrm{NIC}^{(12)}$ and the $\mathrm{NOC}^{(13)}$, respectively. In another research, the comparative mapping of the activities indicated by the nurses with the priority activities and suggested by the NIC for the diagnosis "Ineffective airway clearance" was applied ${ }^{(18)}$.

Such research evidences the use of cross-mapping to show the usefulness of standardized languages in care and mentions the need to develop studies to incorporate nomenclature into Brazilian reality ${ }^{(15-18)}$.

Thus, the idea presented in this text is that the case study and cross-mapping are useful tools to favor the development of clinical reasoning and contribute to the teaching of new elements of nursing practice contained in standardized language systems.

From this perspective, the purpose was to discuss how crossmapping can identify possible voids in clinical practice and make it possible to teach the use of standardized language systems. In order to do so, we sought to evaluate the correspondence of the expected results and nursing prescriptions written by nurses 
with the results contained in the NOC and the actions of the interventions contained in the NIC for the diagnosis "Ineffective peripheral tissue perfusion (00204) “(11).

\section{METHOD}

\section{Ethical aspects}

The research was initiated after approval by the Research Ethics Committee (CEP) of the Universidade Federal de Pernambuco (UFPE).

\section{Type of study}

NANDA-I ${ }^{(11)}, \mathrm{NIC}^{(12)}$, and $\mathrm{NOC}^{(13)}$ taxonomies were used to describe nursing diagnoses, results and interventions using a descriptive design that used the case study. and "cross-mapping" that made it possible to compare nursing records from practice and standardized languages in nursing.

\section{Methodological procedures}

The study was developed in two stages. The first was the elaboration of the case study with validation by the item-objective congruence method, obtaining a content validity index (CVI) of $93.75 \%{ }^{(19)}$. The second step was the registration of the nursing diagnoses, expected results and nursing prescriptions elaborated by the nurses in relation to a case study; for this purpose, participants were given the possibility of using the aforementioned taxonomies. The statements of the nursing phenomena written by the professionals were registered with a usual, non-standardized language ${ }^{(20)}$; for this purpose, the correspondence with the $\mathrm{NOC}^{(13)}$ and the $\mathrm{NIC}^{(12)}$ was verified using cross-mapping.

The mapping data were submitted to validation by a panel of experts. Two judges were invited who had experience in terminologies in nursing, formed more than ten years ago and with master's degree. After the acceptance, the material was sent electronically and requested to mark for each item of the cross mapping whether or not it agreed with the identified correspondence. We used the calculation of agreement index ${ }^{(21)}[\mathrm{Cl}$ $=\mathrm{CN} /(\mathrm{NC}+\mathrm{DN}) \times 100]$, where $\mathrm{CN}$ means the concordance number and DN corresponds to the discordance. The $80 \%$ index was adopted as the minimum level of agreement to be obtained by the judges in the set of evaluated items.

The validation of the mapping of the data regarding the expected results elaborated by the nurses with the results proposed by the $\mathrm{NOC}^{(13)}$ obtained a $100 \%$ concordance index $(\mathrm{Cl})^{(20)}$. In relation to the validation of the mapping of the data on the expected care prescriptions elaborated by the nurses with the interventions suggested by the $\mathrm{NIC}^{(12)}$, a $90 \% \mathrm{CI}$ was obtained ${ }^{(20)}$.

NOC and NANDA-I, including the results to measure the resolution of the diagnosis, to measure the defining characteristics and the results associated to the results, were considered for the mapping of the nursing results elaborated by the nurses to the results proposed by the $\mathrm{NOC}^{(13)}$. related factors or intermediate results ${ }^{(13)}$. Therefore, both the definition of the title and the respective indicators were considered.

Coenen, Ryn and Sutton ${ }^{(22)}$ followed the steps of mapping the prescriptions written by professionals in relation to the actions indicated in the interventions of the $\mathrm{NIC}^{(12)}$, which include the title of the NIC interventions for NIC activities ; use the context of nursing diagnosis; map meanings versus words and, finally, use more specific NIC intervention. In this study, the sequence was adapted: it was based on the context of the diagnosis, the meanings versus the words were mapped and, finally, the choice of the more specific intervention of the NIC was given.

\section{Study scenario}

The research was conducted in public institutions of education and hospital care in a capital of the Northeast Region of the country. The following instruments were submitted by the researcher to the nurses who showed interest and expressed their acquiescence in participating in the research: a form for the characterization of the professional profile; a questionnaire requesting the registration of diagnoses, expected results and nursing prescriptions using the NANDA-I ${ }^{(11)}, \mathrm{NIC}^{(12)}$ and $\mathrm{NOC}^{(13)}$ taxonomies; and the Free and Clarified Consent Term (FCCT). Participants were individually advised to consult the latest version of their taxonomies and informed about the one-week return period. The average time of return of the returned material was one month. The criterion of inclusion for teachers was to be part of disciplines that provide content about the nursing process and about SLSs; for nursing assistants, was the use of printed forms adopted by the hospital for the registration of nursing diagnoses and prescriptions. We selected the clinical units that had the systematization of the nursing assistance implemented.

The data referring to the mapping of results and nursing interventions were extracted from the primary data of the study ${ }^{(20)}$, which examined the different phases of the care process and its relationship with standardized language systems. From these data, it was possible to discuss the contribution of cross-mapping as a teaching and learning tool for clinical practice.

\section{Collection and data organization}

Data collection was carried out by the researcher responsible from July to September 2013. The statements of the nursing phenomena elaborated by the nurses were organized in a spreadsheet of the program Microsoft Office Excel ${ }^{\circledR} 2007$.

\section{Data analysis}

Among the five highly accurate nursing diagnoses ${ }^{(19)}$, it was chosen to analyze, within the scope of this article, to understand the processes involved in the clinical reasoning of professionals and the contribution of taxonomies, only the findings related to the nursing diagnosis "Perfusion ineffective peripheral tissue "(11).

This diagnosis is defined as "reduction of blood circulation to the periphery, capable of compromising health"(11). The clinical evidences of this diagnosis in the case study ${ }^{(19)}$ were: "Pain when raising the leg, with shiny, cold, pallid, swollen skin, with diminished tibial pulse and presence of small and rounded wound in the calcaneus region, pale bed, moderate exudate, and granulation points".

\section{RESULTS}

The statements of the nursing phenomena were obtained from the records of 12 nurses, $91.7 \%$ female, with predominance in 
the age group of 36 to 50 years, with training time and clinical experience between 5 and 20 years. Of the professionals, seven developed activities in public institutions of education and five in institutions of clinical assistance. As to the time of use of the taxonomies adopted, it was verified that $83.4 \%(n=10)$ professionals reported knowing them and employing them for less than 5 years; and $16.7 \%(n=2)$ for more than 6 years.

The data referring to the mapping between the statements made by the nurses and those contained in the NOC for the nursing diagnosis "Ineffective peripheral tissue perfusion $(00204)^{\prime \prime(11)}$ are shown in Chart 1. It is worth noting that the types of categories of results ${ }^{(13)}$ highlighted refer to diagnosis with a focus on the problem ${ }^{(11)}$.

The expected result written by the professional "Will present improvement of the perfusion - absence or decrease of oedema, pain and discomfort when elevating the lower limb and palpable and strong peripheral pulses" was represented by the nursing result "Peripheral tissue perfusion with the following indicators: Oedema (040712) and Pain located at the extremity (040713). However, the omission in the nurse's wording of the "Skin temperature at the extremities (040710)" indicator, present as an indicator of the nursing result "Peripheral tissue perfusion", is added as a void in the knowledge.

In relation to the "palpable and strong peripheral pulses", these can be evaluated by indicators that are in the results to measure the defining characteristics. Thus, the indicator "Peripheral pulses (041403)" was added to the nursing result "Cardiopulmonary Status (0414)". Therefore, the first goal established by the nurse included NOC results to measure the problem and a defining characteristic for the problem.

It is verified that the other two statements elaborated by the nurses as expected results were considered additional, that is, directed to one or more clinical evidences, but not to solve the global problem: "Tissue Integrity: skin and mucous membrane (1101)" with the indicators "Tissue perfusion (110111)" and "Scar tissue (110117)"; and "Wound healing: second intention (1103)" with the indicator "Scar tissue (110117)".

It should be mentioned that the clinical situation presented does not allow the identification of results in the NOC in the category to measure the results associated with related factors or intermediate results.

Considering the care provided in the 19 prescriptions nominated by the nurses, the actions contained in the four nursing interventions proposed in the NIC were mapped: Circulatory
Chart 1 - Mapping of the nursing results elaborated by the nurses in comparison with those proposed by the Nursing Outcomes Classification (NOC) for the diagnosis "Ineffective peripheral tissue perfusion (00204)"

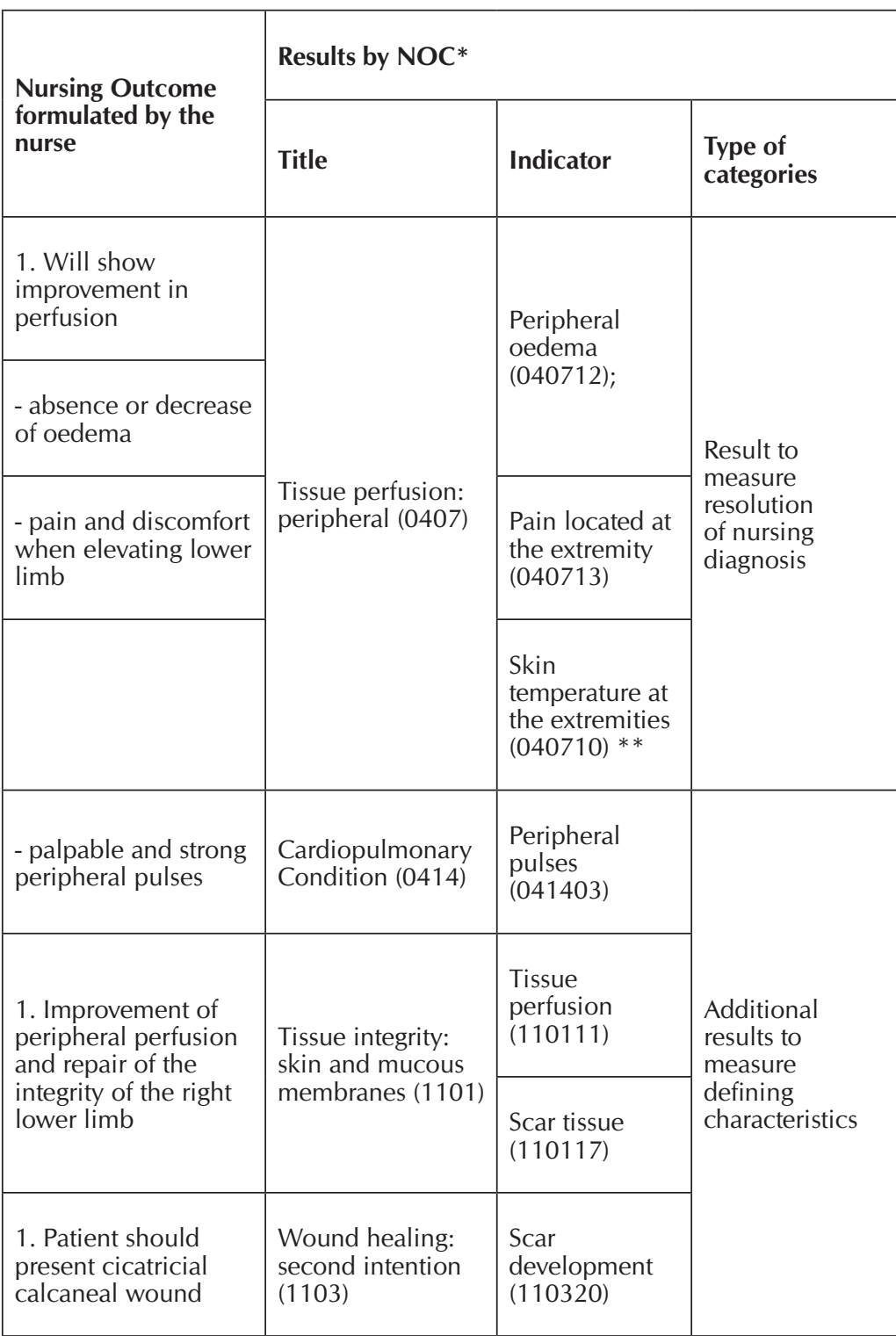

Source: Morais Data ${ }^{20}$

Note: *Nursing Outcomes Classification (NOC); **Indicator not considered by the nurse and pertinent to the presented clinical case.

care: arterial insufficiency (4062); Pressure ulcer care (3520); Prevention of pressure ulcer (3540); and Teaching: disease process (5602) - according to Chart 2.

The majority of the nurses' prescribed care $(n=15)$ for the ineffective diagnosis of peripheral tissue perfusion was mapped in the intervention, classified in the priority level, "Circulatory care: arterial insufficiency (4062)"; the other nursing prescriptions corresponded to the level of interventions suggested: "Teaching: disease process (5602)" and "Prevention of pressure ulcer (3540)"; the nursing intervention "Pressure ulcer care (3520)" is not on the NIC list, related to the diagnosis in question. 
Chart 2 - Mapping of nursing prescriptions elaborated by nurses in comparison to those proposed by the Nursing Interventions Classification (NIC) for the diagnosis "Ineffective peripheral tissue perfusion (00204)"

\begin{tabular}{|c|c|c|}
\hline Nursing Prescriptions & Nursing Activities - NIC * & $\begin{array}{l}\text { Nursing Interventions } \\
\text { - NIC * }\end{array}$ \\
\hline Measure the capillary filling time & \multirow{3}{*}{$\begin{array}{l}\text { Carry out comprehensive evaluation of } \\
\text { peripheral circulation (eg check peripheral } \\
\text { pulses, oedema, capillary filling, color and } \\
\text { temperature) }\end{array}$} & \multirow{15}{*}{$\begin{array}{l}\text { Circulatory care: } \\
\text { arterial insufficiency } \\
(4062)\end{array}$} \\
\hline $\begin{array}{l}\text { Palpate the pulses to determine their presence and } \\
\text { characteristics }\end{array}$ & & \\
\hline $\begin{array}{l}\text { Monitor/measure oedema and capillary filling and pulse } \\
\text { periodically }\end{array}$ & & \\
\hline Measure the circumference of the limbs & Check the ankle-brachial index as appropriate & \\
\hline Evaluate tibial pulse & Evaluate peripheral oedema and pulses & \\
\hline Determine the pain's history and characteristics & $\begin{array}{l}\text { Monitor the degree of discomfort or pain with } \\
\text { exercise, at night, or while resting }\end{array}$ & \\
\hline Keep right lower limb hanging & \multirow{2}{*}{$\begin{array}{l}\text { Position end in dependent position, as } \\
\text { appropriate }\end{array}$} & \\
\hline Elevation of the heated lower limb & & \\
\hline Helping to carry out active and passive mobilization exercises & \multirow{2}{*}{ Encourage the patient to exercise, as tolerated } & \\
\hline Encourage early ambulation when possible & & \\
\hline Keep lower limb warm & \multirow[b]{2}{*}{$\begin{array}{l}\text { Provide heat (eg, extra bedding, increased } \\
\text { room temperature), as appropriate }\end{array}$} & \\
\hline $\begin{array}{l}\text { Perform limb coverage with orthopedic cotton in order to raise } \\
\text { site temperature and improve venous return as well as area } \\
\text { protection) }\end{array}$ & & \\
\hline Keep loose clothing & \multirow{2}{*}{$\begin{array}{l}\text { Orient the patient on factors that interfere with } \\
\text { circulation (eg, smoking, restrictive clothing, } \\
\text { exposure to cold temperatures, and crossing of } \\
\text { legs and feet) }\end{array}$} & \\
\hline Guide patient to avoid crossing legs & & \\
\hline \multirow[t]{3}{*}{$\begin{array}{l}\text { Guide non-stay for long periods in seated or standing } \\
\text { position }\end{array}$} & $\begin{array}{l}\text { Change patient position at least every } 2 \text { hours, } \\
\text { as appropriate }\end{array}$ & \\
\hline & Inspect the skin for ulcers or tissue rupture** & \multirow{2}{*}{$\begin{array}{l}\text { Circulatory care: } \\
\text { arterial insufficiency } \\
(4062)\end{array}$} \\
\hline & Implement wound treatment** & \\
\hline \multirow[t]{2}{*}{$\begin{array}{l}\text { Guidance on the importance of the treatment of the } \\
\text { underlying disease to improve the general }\end{array}$} & $\begin{array}{l}\text { Guide the patient about measures to prevent/ } \\
\text { minimize symptoms, as appropriate }\end{array}$ & \multirow[t]{2}{*}{$\begin{array}{l}\text { Teaching: disease } \\
\text { process (5602) }\end{array}$} \\
\hline & Discuss therapy/treatment options** & \\
\hline \multirow{2}{*}{$\begin{array}{l}\text { Properly moisturize affected limb skin with moisturizing } \\
\text { lotions }\end{array}$} & Moisturize dry skin, still intact & \multirow{2}{*}{$\begin{array}{l}\text { Prevention of pressure } \\
\text { ulcer ( } 3540)\end{array}$} \\
\hline & $\begin{array}{l}\text { Apply protectors to the heels and elbows } \\
\text { when appropriate** }\end{array}$ & \\
\hline Record evolution of wound healing & $\begin{array}{l}\text { Describe the characteristics of the ulcer at } \\
\text { regular intervals, including size (length } \times \\
\text { width } \times \text { depth), stage (I-IV), location, exudate, } \\
\text { granular or necrotic tissue and epithelization }\end{array}$ & \multirow{3}{*}{$\begin{array}{l}\text { Pressure ulcer care*** } \\
(3520)\end{array}$} \\
\hline \multirow[t]{2}{*}{ Daily bandage appliance on the lesion of the right lower limb } & Apply bandages when appropriate & \\
\hline & $\begin{array}{l}\text { Monitor for signs and symptoms of wound } \\
\text { infection** }\end{array}$ & \\
\hline
\end{tabular}

Source: Morais Data ${ }^{(20)}$.

Note: *Nursing Interventions Classification (NIC) **Nursing activities not considered by the nurse and pertinent to the presented clinical situation. ${ }^{* * *}$ The NIC "Pressure ulcer care (3520)" intervention is categorized as suggested for the diagnoses "Impaired skin integrity" and "Impaired tissue integrity"(12). 


\section{DISCUSSION}

In regard to the nursing result "Tissue perfusion: peripheral (0407)", this is defined as "adequacy of blood flow through the small vessels of the extremities to maintain tissue function". It is located, in the taxonomy, in the Physiological Health domain; class, Cardiopulmonary ${ }^{(13)}$. The indicators "Peripheral oedema (040712)", "Pain located at the extremity (040713)" and "Skin temperature at the extremities (040710)" of this result justifies such selection because it allows evaluation of peripheral circulation and discomfort. When present, signs of cold, hypoxic and oedema skin signify a reduction of blood flow, a decrease in temperature and interference in the transport of oxygen that compromises the nutrition of the tissues in formation ${ }^{(23)}$. The symptom "discomfort" can be minimized as oedema reduction, improvement of tissue perfusion and pain control occur.

However, "Tissue Integrity: Skin and Mucous Membranes (1101)" means "structural integrity and normal physiological function of the skin and mucous membranes". The result "Wound healing: second intention (1103)" is defined as "extent of regeneration of cells and tissues after intentional closure. Both are in the NOC, in the Physiological Health domain; class; Tissue Integrity ${ }^{(13)}$. The selected indicators of these NOC results - "Tissue perfusion (110111)", "Tissue scar (110117)" and "Scar development (110320)" - are fundamental to evaluate the cicatricial process. The decrease of blood and oxygen prevents the synthesis of collagen, decreases cellular proliferation and migration, so compromising wound healing (23).

When examining data from nurses' records in the situation studied, we can consider that indicators were identified to measure the problem resolution and others related to measuring the defining characteristics; in addition, they allow, through cross-mapping, to identify gaps in care planning. One example is the omission of the indicator "Temperature of the skin at the extremities (040710)", considering that this signal was presented in the (fictitious) case study and considered a differentiator in the evaluation of the irrigated tissue and the ischemic tissue ${ }^{(23)}$. Therefore, although the results proposed by the nurses have relevance, expressed by the correspondence with the literature (NOC), it can be considered that other pertinent results could have been included (Chart 1).

In the case of the nursing interventions mapped in the NIC, these are at the priority and suggested levels (Chart 2). Priority intervention expresses a good correspondence with the etiology and/or the defining characteristics of the diagnosis, and the proposed activities aim to solve the problem. In the case of the suggested interventions, these are mentioned less frequently than the previous one and can only address the etiological factors or defining characteristics $(\mathrm{NIC})^{(12)}$.

In relation to the nursing interventions mapped in the NIC for the diagnosis in question, it is possible to evaluate the individual at a given moment and to follow the post-intervention changes through the indicators. Regarding the intervention "Circulatory care: arterial insufficiency (4062)", the indicators described in the result "Peripheral tissue perfusion (0407)" allow to measure and monitor the improvement or deterioration of the peripheral circulation. For the intervention "Pressure ulcer care (3520)", indicators related to "Tissue integrity: skin and mucous membranes (1101)" and "Wound healing: second intention (1103)" are relevant because of the need to evaluate the cicatricial process inflammatory, proliferative and repair phases ${ }^{(23-26)}$.

Regarding the vacancies in the selection of nursing activities for each mapped nursing intervention, it was verified that, in the intervention "Circulatory care: arterial insufficiency (4062)", other activities should be included, such as skin inspection for ulcers or rupture of the tissue and implementation of wound treatment. In the intervention "Teaching: disease process (5602)", the activity "discussing therapy/treatment options" should be considered because it preserves patients' right to decisions about their care and treatment ${ }^{(24)}$.

The "Prevention of pressure ulcer (3540)"(12) intervention, in particular the "apply heel and elbow protectors when appropriate" activity, as well as the "Pressure ulcer care (3520)" the activity "monitor for signs and symptoms of wound infection", are relevant to the clinical signs presented in the case study and should have been considered. Therefore, it is recognized that the aforementioned activities are important for the prevention of pressure injury since the assessment of skin conditions and pressure relief devices are used to aid in the discontinuation of local cell hypoxia. Monitoring of signs and symptoms of infection is considered a primary care to promote an environment conducive to healing, secretion-free and necrotic tissue ${ }^{(25-26)}$.

Another aspect to which the mapping contributed was the analysis of the clinical reasoning, in the correlation of the expected results with the prescriptions. It is desirable that each prescribed action be measured by previously established performance indicators. In this perspective, the actions prescribed by the nurses "Guide the patient about measures to prevent/minimize the symptoms, as appropriate" and "Moisturize the dry skin, still intact", located in the nursing interventions "Prevention of pressure ulcer (3540)" and "Teaching: disease process (5602)", were not related to established results. However, it is important to highlight the pertinence of the interventions in the clinical case presented. That is, in this case, the indicator "Benefits of disease control (1803)" of the result "Knowledge: disease process (1803)" and indicator "Hydration (110104)" should be included in the result "Tissue integrity: skin and mucous membranes (1101)."

Using the mapping as a source of void identification of nurses' knowledge has shown to be a viable strategy to be incorporated into the nurses training and improvement process, as it allows for a review of clinical reasoning, an accurate clinical practice and on the registration of the stages of the nursing process through a uniform language. To document nursing care through a standardized language system is to ensure uniform communication, a description of the uniqueness of nursing, and the storage of data for educational purposes in decision making and/or statistical data ${ }^{(5,7,15-18)}$.

\section{Limitation of the study and contributions to the nursing area}

In spite of the lack of similar publications to examine the results obtained on the use of cross-mapping as a facilitating tool to discuss the diagnostic and therapeutic reasoning, as well as the presentation of data referring to only one nursing diagnosis, it was possible to exemplify the potential of the contributions of standardized language systems to naming, organizing clinical 
nursing practice, and identifying knowledge gaps in this context, by means of cross-mapping from the data of a fictitious case.

\section{CONCLUSION}

Based on the data presented, the case study and cross-mapping showed that they are strategies that educators can use in teaching to stimulate the development of cognitive ability and to evaluate both clinical practice in the search for quality of care and the use of nursing classifications for the organization of health information.

Cross-mapping enabled researchers to match nurses' results to nursing outcomes and those contained in the nursing outcomes classification, as well as between the prescriptions of care established by these professionals and the activities contained in the interventions proposed by the classification of nursing interventions. Mapping is recognized as a didactic material to verify the pertinence of clinical decision-making.

\section{FUNDING}

The authors are grateful for the financial support of the Coordination for the Improvement of Higher Education Personnel (CAPES) and the National Council for Scientific and Technological Development (CNPq).

\section{REFERENCES}

1. Herdman HT. The nursing process: a time to remember its purpose. Rev Rene [Internet]. 2013[cited 2016 Jan 20];14(3):458-9. Available from: http://www.revistarene.ufc.br/revista/index.php/revista/article/view/1396

2. Conselho Federal de Enfermagem-COFEN. Resolução COFEN No 358 do Conselho Federal de Enfermagem, de 15 de outubro de 2009[Internet]. 2009[cited 2016 Jan 20]. Available from: http://www.cofen.gov.br/resoluo-cofen-3582009 4384.html

3. Conselho Federal de Enfermagem-COFEN. Resolução COFEN N429, de 30 de maio de 2012. [Internet]. 2009[cited 2016 Jan 20]. Available from: http://www.cofen.gov.br/resoluo-cofen-n-4292012_9263.html

4. Carvalho EC, Cruz DALM, Herdman TH. Contribuição das linguagens padronizadas para a produção do conhecimento, raciocínio clínico e a prática clínica da enfermagem. Rev Bras Enferm[Internet]. 2013[cited 2016 May 10];66(Spe):134-41. Available from: http://www.scielo.br/pdf/reben/v66nspe/v66nspea17.pdf

5. Müller-Staub M, Graaf-Waar H, Paans W. An internationally consented standard for nursing process-clinical decision support systems in electronic health records. Comp Inform Nurs[Internet]. 2016[cited 2016 Nov 15];34(11):493-501. Available from: http://journals. Iww.com/cinjournal/pages/articleviewer.aspx? year $=2016 \&$ issue $=11000 \&$ article $=00003 \&$ type $=$ abstract

6. Kautz DD, Van Horn ER. An exemplar of the use of NNN Language in developing evidence-based practice guidelines. Int J Nurs Terminol Classif[Internet]. 2008[cited 2016 Jan 10];19(1):14-9. Available from: http://onlinelibrary.wiley.com/ doi/10.1111/j.1744-618X.2007.00074.x/epdf

7. Chianca TCM, Salgado PO, Albuquerque JP, Campos CC, Tannure MC, Ercole FF. Mapping nursing goals of an Intensive Care Unit to the Nursing Outcomes. Rev Latino-Am Enfermagem[Internet]. 2012[cited 2016 Nov 15];20(5):854-62. Available from: http:// www.scielo.br/pdf/rlae/v20n5/06.pdf

8. Nonnenmacher CL, Ávila CW, Mantovani VM, Vargas MAO, Echer IC, Lucena AF. Cross mapping between the priority nursing care for stroke patients treated with thrombolytic therapy and the nursing interventions classification-NIC. Int J Nurs Knowl[Internet]. 2016[cited 2016 Nov 15];28(4):171-7. Available from: http://onlinelibrary.wiley.com/doi/10.1111/2047-3095.12147/epdf

9. Nonino FOL, Napoleão AA, Carvalho EC, Perilli Filho SF. A utilização do mapeamento cruzado na pesquisa de enfermagem: uma revisão da literatura. Rev Bras Enferm[Internet]. 2008[cited 2016 Jan 10];61(6):872-7. Available from: http://www.scielo.br/pdf/ reben/v61n6/a13v61n6.pdf

10. Carvalho EC, Kusumota L. Nursing process: difficulties for its utilization in practice. Acta Paul Enferm[Internet]. 2009 [cited 2016 Nov 15];22(Esp-Nefrol):554-7. Available from:http://www.scielo.br/pdf/ape/v22nspe1/en_22.pdf

11. NANDA. Diagnóstico de enfermagem da NANDA: definições e classificação 2015-2017. Porto Alegre: Artmed; 2015.

12. Bulechek MG, Butcher HK, Dochterman JM, Wagner CM. Classificação das Intervenções de Enfermagem. Rio de Janeiro: Elsevier; 2016.

13. Moorhead S, Johnson M, Maas ML, Swanson E. Classificação dos Resultados de Enfermagem. Rio de Janeiro: Elsevier; 2016.

14. Carvalho EC, Oliveira-Kumakura ARS, Morais SCRV. Clinical reasoning in nursing: teaching strategies and assessment tools. Rev Bras Enferm [Internet]. 2017 [cited 2017 Jun 01];70(3):662-8. Available from: http://www.scielo.br/pdf/reben/v70n3/0034-7167reben-70-03-0662.pdf

15. Tosin MHS, Campos DM, Andrade LT, Oliveira BGB, Santana RF. Nursing interventions for rehabilitation in Parkinson's disease: cross mapping of terms. Rev Latino-Am Enfermagem[Internet]. 2016[cited 2016 Nov 15];24: e2728. Available from: http://www. scielo.br/pdf/rlae/v24/0104-1169-rlae-24-02728.pdf

16. Salgado PO, Chianca TCM. Identification and mapping of the nursing diagnoses and actions in an Intensive Care Unit. Rev LatinoAm Enfermagem[Internet]. 2011[cited 2016 Jan 15];19(4):928-35. Available from: http://www.scielo.br/pdf/rlae/v19n4/11.pdf

17. Oliveira FP, Oliveira BGRB, Santana RF, Silva BP, Candido JSC. Nursing interventions and outcomes classifications in patients with 
wounds: cross-mapping. Rev Gaúcha Enferm[Internet]. 2016[cited 2016 May 15];37(2):e55033.Available from: http://seer.ufrgs.br/ index.php/RevistaGauchadeEnfermagem/article/view/55033/37418

18. Napoleão AA, Carvalho EC. Aplicabilidade de intervenções prioritárias da NIC para diagnóstico de enfermagem desobstrução ineficaz de vias aéreas. Cogitare Enferm[Internet]. 2007[cited 2017 Jan 15];12(1):9-19. Available from: http://revistas.ufpr.br/ cogitare/article/view/8258/5774

19. Morais SCRV, Nóbrega MML, Carvalho EC. Convergence, divergence and diagnostic accuracy in the light of two nursing terminologies. Rev Bras Enferm[Internet]. 2015[cited 2017 May 30];68(6):1086-92. Available from: http://www.scielo.br/pdf/reben/ v68n6/en_0034-7167-reben-68-06-1086.pdf

20. Morais SCRV. Fenômenos de enfermagem identificados por enfermeiros em um caso clínico: considerações à luz das classificações da NANDA-I, NOC e NIC e a CIPE ${ }^{\circledast}$. [Tese]. Escola de Enfermagem de Ribeirão Preto, Universidade de São Paulo; 2014.

21. Waltz CF, Strickland OL, Lenz ER. Measurement in nursing and health research. 3th. ed. Springer; 2005.

22. Coenen A, Ryan P, Sutton J. Mapping nursing interventions from a hospital information system to the Nursing Interventions Classifications (NIC). Nurs Diag[Internet]. 1997[cited 2016 Jan 15];8(4):145-51. Available from: http://onlinelibrary.wiley.com/ doi/10.1111/j.1744-618X.1997.tb00469.x/epdf

23. Burihan E, Baptista-Silva JCC. O Exame Vascular. In: Pitta GBB, Castro AA, Burihan E. Angiologia e Cirurgia Vascular. Guia ilustrado. UNCISAL/ECMA; 2003.

24. Chaves PL, Costa VT, Lunardi VL. A Enfermagem frente aos direitos de pacientes hospitalizados. Texto Contexto Enferm[Internet]. 2005[cited 2016 Nov 10];14(1):38-43. Available from: http://www.scielo.br/pdf/tce/v14n1/a05v14n1.pdf

25. Bavaresco T, Lucena AF. Nursing Intervention Classifications-NIC validated for patients at risk of pressure ulcers. Rev Latino-Am Enfermagem[Internet]. 2012[cited 2016 Jun 10];20(6):1109-16. Available from: http://www.scielo.br/pdf/rlae/v20n6/13.pdf

26. Rolim JA, Vasconcelos JMB, Caliri MHL, Santos IBC. Prevenção e tratamento de úlceras por pressão no cotidiano de enfermeiros intensivistas. Rev Rene [Internet]. 2013[cited 2017 May 30];14(1):148-57. Available from: http://www.revistarene.ufc.br/revista/ index.php/revista/article/viewFile/336/pdf 